\title{
Biomarkers in Critical Care
}

Editor

MITCHELL M. LEVY

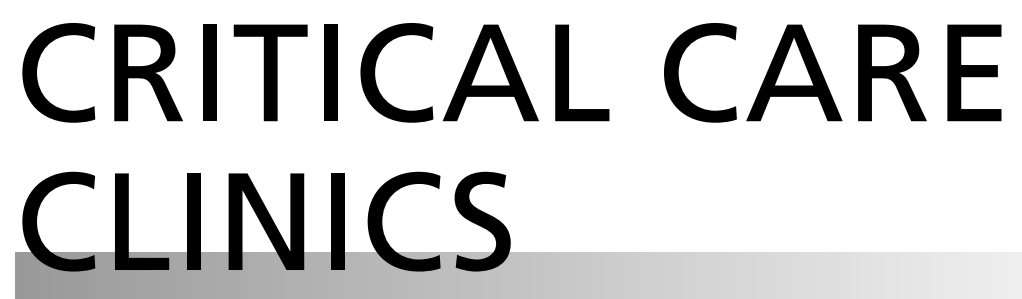

www.criticalcare.theclinics.com

Consulting Editor

JOHN A. KELLUM

January 2020 • Volume 36 • Number 1 